\title{
Brachyplatystoma promagdalena, new species, a fossil goliath catfish (Siluriformes: Pimelodidae) from the Miocene of Colombia, South America
}

\author{
John G. Lundberg
}

\begin{abstract}
A fossil Weberian complex of a large pimelodid catfish from the middle Miocene La Venta fauna of central Colombia originally identified as Brachyplatystoma sp. is described as a new, extinct species. Brachyplatystoma promagdalena, new species, is diagnosed by three autapomorphic characters: fifth centrum with a massive midventral expansion containing deep cavities and heavy ridges; first and compound centra contribute to a pair of prominent anterolateral processes before the ventral ends of the ossa suspensoria; and compound centrum with an anteriorly concave low ridge crossing its ventral surface posterior to aortic canal foramen. Brachyplatystoma promagdalena is compared to modern congeneric species and placed in the subgenus Malacobagrus with B. filamentosum, B. capapretum and B. rousseauxii. This group is characterized by synapomorphies of the texture and form of the first vertebra; texture and form of the dorsal side of the fourth transverse process; and presence of a bony gas bladder platform on the ventral side of the fourth transverse process. Today Brachyplatystoma ranges widely across the lowland Orinoco and Amazon and some river basins of the Guianas. The genus does not occur west or north of the Andes or Venezuelan coastal ranges. The Miocene species of Brachyplatystoma signals the former large river and biotic connection between the paleo-Amazonas-Orinoco system and central Colombia, a region now drained by the río Magdalena. Other fossils of aquatic vertebrates from the La Venta fauna show this same biogeographic relationship.
\end{abstract}

Um complexo de Weber fóssil de um grande bagre pimelodideo do Mioceno Médio da fauna de La Venta, Colombia central, originalmente identificado como Brachyplatystoma sp., é descrito como uma espécie nova e extinta. Brachyplatystoma promagdalena, espécie nova, é diagnosticada por três caracteres apomórficos: quinto centro vertebral com uma expansão médioventral massiva contendo cavidades profundas e cristas robustas; o primeiro centro e o centro composto contribuem com um par de processos anterolaterais proeminentes antes das terminações ventrais dos ossa suspensoria; e centro vertebral composto com uma crista baixa côncava cruzando sua superfície ventral posterior ao forame do canal aórtico. Brachyplatystoma promagdalena é comparada às espécies congenéricas modernas e posicionado no subgênero Malacobagrus com $B$. filamentosum, B. capapretum e B. rousseauxii. Este grupo é caracterizado por sinapomorfias na textura e forma da primeira vertebra; textura e forma do lado dorsal do quarto processo transverso; e presença de uma plataforma óssea da bexiga natatória no lado ventral do quarto processo transverso. Atualmente Brachyplatystoma se distribui amplamente nas terras baixas do Orinoco e Amazonas e em algumas bacias hidrográficas das Guianas. O gênero não ocorre a oeste ou ao norte dos Andes ou em zonas costeiras Venezuelanas. A espécie de Brachyplatystoma do Mioceno indica a existência de uma antiga conexão física e biótica entre o sistema paleo-Amazonas-Orinoco e a Colômbia central, uma região atualmente drenada pelo río Magdalena. Outros fósseis de vertebrados aquáticos da fauna de La Venta apresentam a mesma relação biogeográfica.

Key words: Malacobagrus, Weberian vertebrae, Paleontology, La Venta fauna, Villavieja Formation.

\section{Introduction}

The middle Miocene Honda Group continental beds in the Magdalena Valley of Colombia have yielded thousands of vertebrate fossils comprising the La Venta fauna (Kay et al., 1997). Among these is a distinctive, partial Weberian vertebral complex of a large pimelodid catfish from the Villavieja
Formation, previously reported as Brachyplatystoma sp. (Lundberg, 1997, 1998). Like several other aquatic taxa from the Miocene La Venta fauna, the fossil goliath catfish signals a previously widespread Amazonian-Orinocoan biota that was diminished during or after about 12 - $11 \mathrm{Ma}$ with the final uplift of the Eastern Andes and concomitant isolation of the Magdalena Valley. Comparison of the La Venta specimen to a

Department of Ichthyology, The Academy of Natural Sciences, 1900 Benjamin Franklin Parkway, Philadelphia, PA 19103, USA. email: lundberg@acnatsci.org 


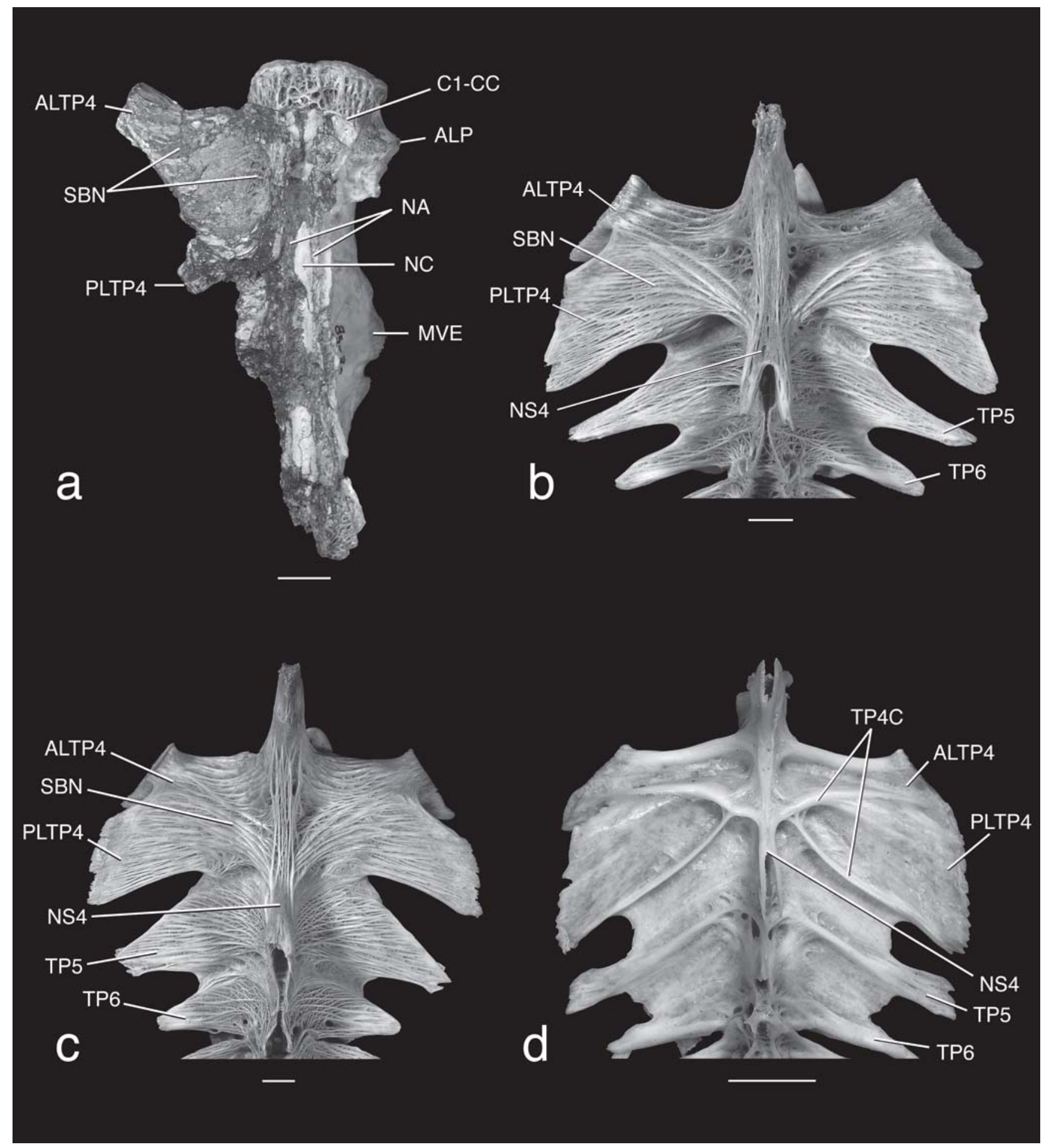

Fig. 1. Weberian complexes in dorsal view of the fossil and modern Brachyplatystoma species, a, B. promagdalena, IGM183062, b, B. filamentosum, DU F1052, from the río Apure, Venezuela ; c, B. rousseauxii, DU F1078, from the río Apure, Venezuela ; d, B. vaillantii, DU F1034, from the río Apure, Venezuela. Scale bars equal to $1 \mathrm{~cm}$. Abbreviations: ALP, anterolateral processes; ALTP4, anterior limb of fourth transverse process; C1-CC, First centrum-compound centrum joint; MVE, midventral expansion on fifth centrum; NA, neural arch; NC, neural canal; NS4, neural spine of fourth vertebra; PLTP4, posterior limb of fourth transverse process; SBN, spongy bone, TP4C, crests on fourth transverse process, TP5, fifth transverse process; TP6, sixth transverse process. 
large and growing collection of modern pimelodid skeletons, combined with an ongoing phylogenetic characterization of genera and higher groups within the family (Lundberg \& Parisi, 2002; Lundberg \& Akama, 2005), now confirms the identification of the Colombian fossil as belonging to the distinctive subgenus Malacobagrus of Brachyplatystoma. Furthermore, the fossil exhibits a combination of attributes that distinguish it from all other pimelodids. Herein this fossil vertebral complex is described and illustrated in detail, and used to recognize and place a new extinct species $B$. promagdalena.

\section{Materials and Methods}

The fossil Weberian complex was cleaned of its unconsolidated sandy matrix with needle and brush. Comparisons were made to the modern skeletons of pimelodid catfishes listed in Lundberg et al. (1991), Lundberg \& Parisi (2002) and Lundberg \&Akama (2005). Included in this material are specimens (numbers in parentheses) of all species of Brachyplatystoma and their sister taxon Platynematichthys: $B$. vaillantii (7), B. rousseauxii (7), B. filamentosum (10), B. capapretum (5), B. juruense (3), B. platynemum (5), B. tigrinum (1) and P. notatus (5). Institutional abbreviations: ANSP Academy of Natural Sciences, Philadelphia, PA, USA; DU Duke University vertebrate collection (housed at ANSP); IGM paleontological collection of INGEOMINAS, Bogotá, Colombia.

\section{Brachyplatystoma promagdalena, new species}

Figs. 1a, 2a, 3, 4a, 5a, 6a

Brachyplatystoma sp. Lundberg, 1997:78 (description, occurrence, fig, 5.7A, p. 78); Lundberg et al., 1998: 23 (listed); Lundberg, 1998:59 (listed); Gayet \& Meunier, 2003: 507 (listed).

Holotype. IGM 183062, a three-dimensional, partial but undistorted anterior section of the vertebral column, the Weberian complex, including first six centra, of which second through fourth are fused as the Weberian compound centrum (Chardon, 1968), plus proximal ends of left fourth and fifth transverse processes. Maximum dimensions of specimen are: length $89.9 \mathrm{~mm}$, width $50.2 \mathrm{~mm}$, and depth $35.0 \mathrm{~mm}$. An epoxy cast of the holotype, ANSP 180898, is deposited at the Department of Ichthyology, Academy of Natural Sciences, Philadelphia.

Locality and Geological Age. Miocene Villavieja Formation of the Honda Group in the southern end of the río Magdalena basin near the town of Villavieja, Huila Department, Colombia at approx. $3^{\circ} 5^{\prime} \mathrm{N}, 75^{\circ} 13^{\prime} \mathrm{W}$ (map in Guerrero, 1997, fig. 2.1, p. 16). The lowest part of the Villavieja Formation or "Fish Bed" from which the fossil came has been 40Ar/39Ar dated at 13.012.8 Ma (Guerrero, 1997).

Diagnosis. An extinct species of Brachyplatystoma, subgenus Malacobagrus, distinguished by three uniquely autapomorphic features of the anterior vertebrae. 1) Fifth cen- trum with a prominent midventral expansion (Figs. 1a, 2a, 3, $4 a, 5 a)$ that is coarsely sculptured with deep cavities and heavy ridges. This expansion is a central attachment site of the swim bladder; 2) Compound centrum with relatively prominent anterolateral processes before the ventral ends of the ossa suspensoria (Figs. 1a, 2a, 3, 4a); 3) Compound centrum with low but clearly defined transverse ridge crossing its ventral surface in an anteriorly concave curve posterior to aortic canal foramen and anterolateral processes (Figs. 2a, 3, 4a, 5a). This ridge is not to be mistaken as an intervertebral joint with the first centrum.

Brachyplatystoma filamentosum and B. capapretum of the subgenus Malacobagrus have moderately expanded attachment sites for the gas bladder on the fifth centrum with surface irregularities but not as coarsely rugose as in the new species (Figs. 2b, 4b, 5b). Other species of the subgenus Malacobagrus (Figs. 2c, 4c, 5c) plus B. vaillantii (Figs. 2d, $4 \mathrm{~d}, 5 \mathrm{~d}$ ) and $B$. tigrinum have weaker anterolateral processes on the compound centrum, and a vaguely delimited ventral ridge on the compound centrum. Brachyplatystoma platynenum and $B$. juruense have prominently sharp and vertically elevated bony collars around the compound centrum.

Etymology. The name promagdalena is applied here as a noun in apposition to the neuter generic name Brachyplatystoma, and refers to the spatiotemporal provenance of the fossil species in central Colombia before the valley of the río Magdalena was formed by uplift of the Eastern Andes.

Description. Figs. 1a, 2a, 3, 4a, 5a and 6a illustrate and identify the features described below. On its dorsal surface the Weberian complex has broken neural arch material flanking the neural canal beginning behind first centrum from the compound to sixth centra, and on the left side the proximal parts of the enlarged fourth transverse process and only the base of fifth transverse process. The ventral side is dominated by a wide first centrum, anteriorly broadened compound centrum with the anterior foramen of a long deeply embedded aortic canal within the compound, fifth and sixth centra, transverse ridge and paired ossa suspensoria, and broadly pitted gas bladder attachment site on the fifth centrum. The salient features of the left and right sides are the enlarged first centrum, anterolateral processes and ossa suspensoria of the compound centrum, followed by deeply vertical, smooth surfaces covered by a veneer of superficial ossification on the compound, fifth and sixth centra.

The first vertebra comprises a centrum only without neural arches, zygapophyses or transverse processes. The first centrum is coarsely sponge-like in texture; its articulation surface for the basioccipital is that of a typical vertebra, cardiform, slightly concave and surrounded by a thick, rugose rim; the central focus of growth rings on the anterior face is three times closer to dorsal rim than ventral rim. The joint between the first and compound centra is straight and nonsutural dorsally just anterior to the neural arches and transverse processes of the compound centrum, otherwise the joint 
is deeply and complexly sutural. The first centrum contributes a small laterally raised projection to each anterolateral process of the compound centrum.
The compound centrum is about 2.6 times the dorsolateral length of the first centrum. The anterior end of the compound centrum carries the bases of the paired fourth trans-

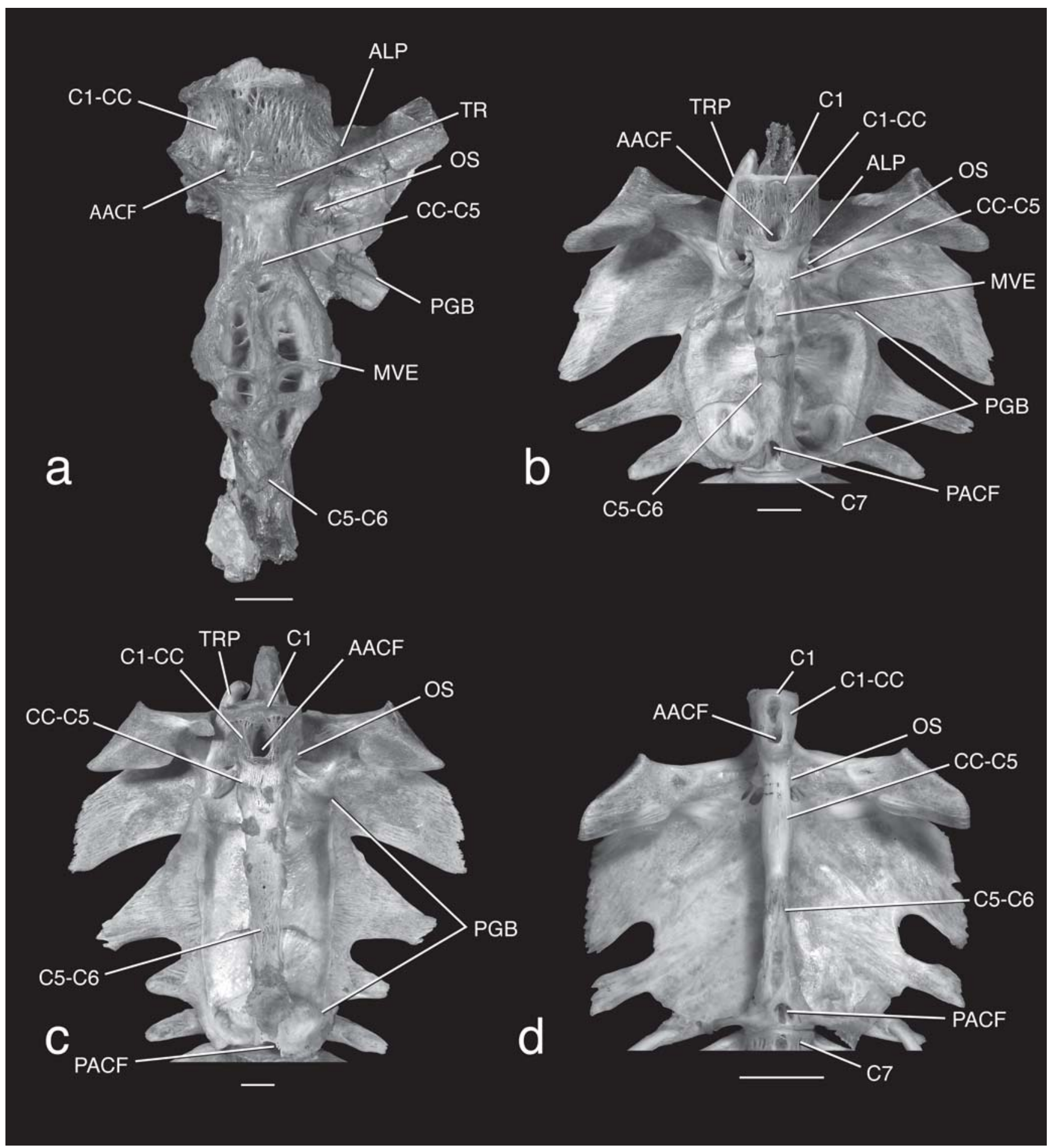

Fig. 2. Weberian complexes in ventral view of the fossil and modern Brachyplatystoma species, a, B. promagdalena, IGM183062, b, B. filamentosum, DU F1052, c, B. rousseauxii, DU F1078, d, B. vaillantii, DU F1034. Scale bars equal to $1 \mathrm{~cm}$. Abbreviations as in Fig. 1 plus: AACF, aortic canal anterior foramen; C1, first centrum; C7, seventh centrum; C5-C6, fifth centrum- sixth centrum joint; $\mathrm{CC}-\mathrm{C} 5$, compound centrum- fifth centrum joint; $\mathrm{OS}$, os suspensorium; $\mathrm{PACF}$, aortic canal posterior foramen; PGB, gas bladder platform; TR, transverse ridge; TRP, tripus. 


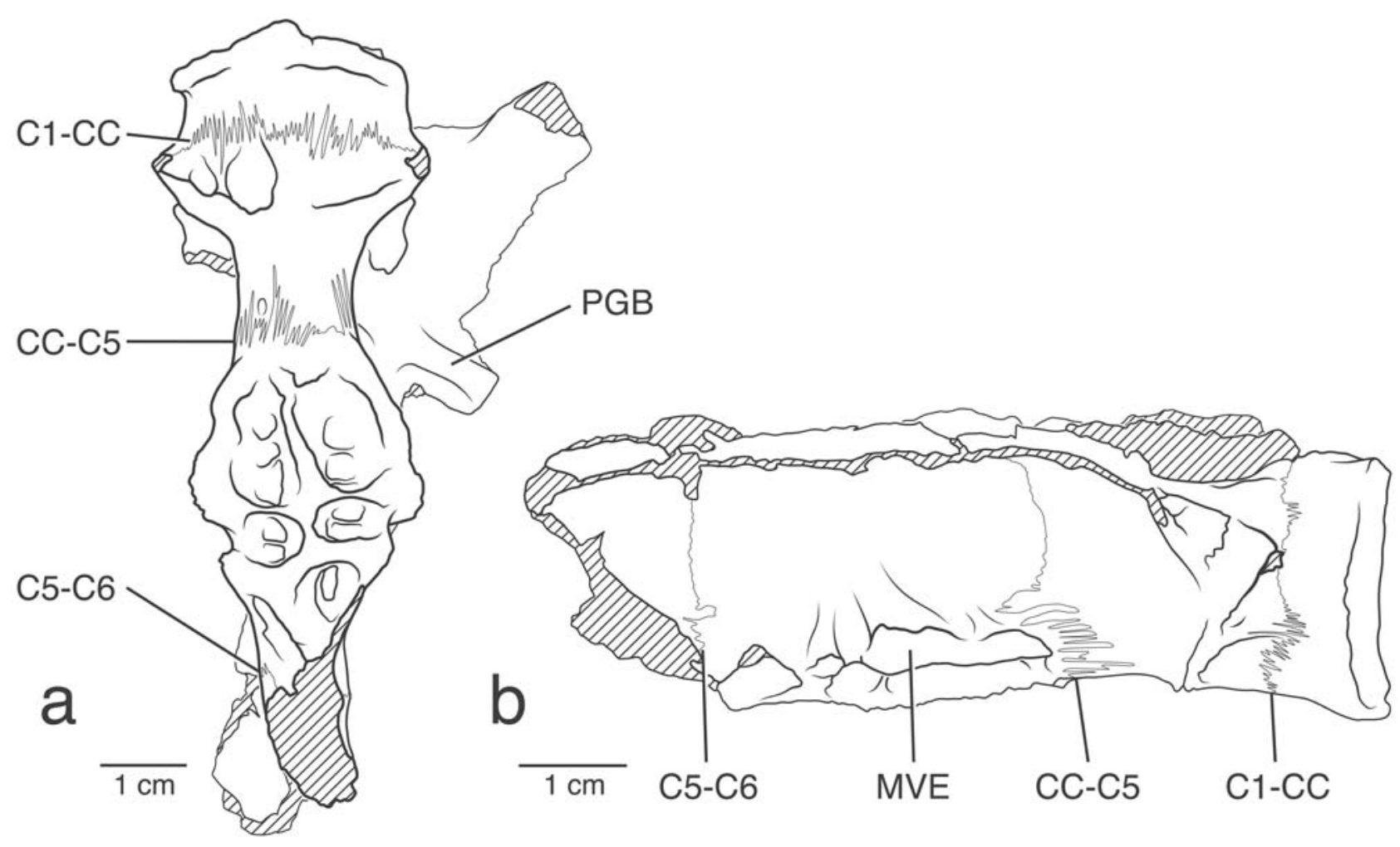

Fig. 3. Weberian complex of the fossil Brachyplatystoma promagdalena, IGM183062; a, ventral view, b, right lateral view. Abbreviations as in Figs. 1 and 2.

verse processes, paired anterolateral processes in front of and adjacent to lower ends of the ossa supensoria, and wide aortic canal foramen followed posteriorly by a curved raised ridge (not to be confused with an intervertebral joint). The aortic canal anterior foramen is asymmetrically placed to the right side and flanked on its right by a small pit. Each os suspensorium runs from below the proximal end of the fourth transverse process anteroventrally to the anterolateral process. Paired shallow channels for the postcardinal veins course obliquely along the dorsal sides of their respective os suspensorium; the right cardinal vein channel is about twice the diameter of the left reflecting an asymmetry of the size of these major blood vessels that is common in Siluriformes. The fourth transverse process is horizontal, flat except for a shallow concavity near the neural arch, and lacks prominent transverse crests. The dorsal surface of fourth transverse process has spongy or finely trabeculated texture; the ventral surface is covered with dense, smooth veneer of superficial ossification like that of the adjacent centra. Proximally the anterolateral limb of the fourth transverse process forms a wide, flat-roofed trough above the os suspensorium (trough occupied by the tripus in articulated skeletons but missing from fossil); trough terminating distally at an abrupt distal expansion. The posterior limb of the fourth transverse process arises behind base of the os suspensorium, projects posterolaterally about $45^{\circ}$ off longitudinal axis, and is thickened reflecting the development of the bony gas bladder plat- form. The compound centrum has a flattened ventral surface; its ventrolateral corners abruptly curve dorsad. The joint between the compound and fifth centra is deeply and complexly sutural across ventral midline in front of the expanded gas bladder attachment site, then laterally abutting and scarcely suturing along vertical sides of centra.

The fifth centrum is longer than the combined lengths of the first and compound centra. The much expanded ventromedian gas bladder attachment site contains five large, irregular pits and several smaller pits separated by heavy walls and ridges. The sides of the fifth centrum are laterally compressed and dorsally constricted above the gas bladder attachment site. The proximalmost part of the fifth transverse process forms a horizontal shelf in line with the fourth transverse process. The fifth and sixth centra greatly compressed along their shallow sutural joint. The sixth centrum, like the fifth, is compressed and has vertical sidewalls; its transverse process and posterior end are broken.

\section{Discussion}

The Weberian vertebral complex of $B$. promagdalena shares structurally rich and informative characters with nested groups within the Pimelodidae. Membership of $B$. promagdalena in the family Pimelodidae sensu Lundberg \& Littmann (2003) is indicated by the deeply sutural and immoveable joint between the fifth and sixth centra (Figs. 2a, 3) 


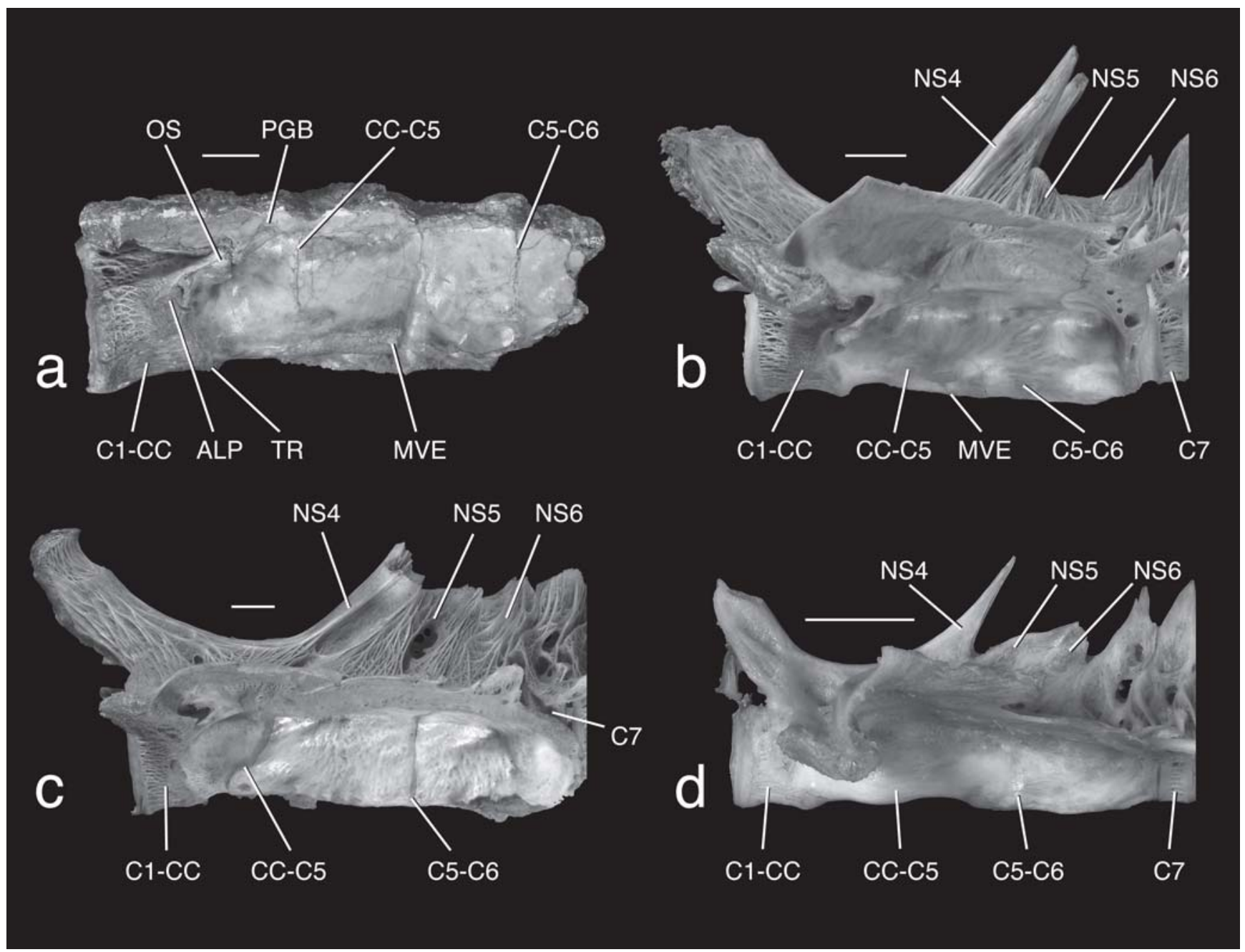

Fig. 4. Weberian complex in left lateral view of the fossil and modern Brachyplatystoma species, a. B. promagdalena, IGM183062, b. B. filamentosum, DU F1052, c. B. rousseauxii, DU F1078, d. B. vaillantii, DU F1034. Scale bars equal to $1 \mathrm{~cm}$. Abbreviations as in Figs. 1 and 2 plus: NS5, neural spine of fifth vertebra; NS6, neural spine of sixth vertebra.

rather than the primitively abutting joint or otherwise modified intervertebral joints found in other Neotropical catfishes. Among the Pimelodidae the fossil has the long bony aortic canal within the compound and fifth or sixth centra (Figs. 2-5) that characterizes a clade (informally named "Group A" by Lundberg et al., 1988, 1991, Lundberg \& Aguilera, 2003) containing all pimelodid genera except Steindachneridion, Phractocephalus, Leiarius and Perrunichthys. These last four genera retain a plesiomorphically open aortic groove on the ventral side of the anterior vertebrae. Also, $B$. promagdalena has the apomorphically extensive development of superficial ossification ventrally and laterally on the compound to sixth centra (Figs. 2-5) as found in most "Group A" pimelodids (Lundberg et al., 1991).

Brachyplatystoma promagdalena possesses three newly found and one previously described synapomorphies (Figs. 1a-c) unambiguously placing the fossil species in Malacobagrus with B. rousseauxii, B. filamentosum, and $B$. capapretum: spongy bone texture of the first vertebra; spongy bone texture of the dorsal surface of the fourth transverse process; lack of transverse crests on the dorsal side of the fourth transverse process; presence of a bony gas bladder platform on the ventral side of the fourth transverse process (Lundberg \& Akama, 2005). In contrast the other species of Brachyplatystoma (Fig. 1d) and their sister group Platynematichthys have a more densely ossified first centrum and fourth transverse process, and one or two prominent ridges radiating transversely from the insertion of the fourth neural spine. These species also lack the gas bladder platform below the fourth transverse process.

Within Malacobagrus, the autapomorphic and diagnostic features of $B$. promagdalena both distinguish the species and exclude it as a potential stem species of any of its congeneric species. No characteristics of the complex anterior vertebrae of this fossil species can be interpreted as plesiomorphic relative to all other species in Malacobagrus. Beyond this available character evidence does not resolve the relationships of the fossil. Brachyplatystoma promagdalena shares three presumed derived features with $B$. rousseauxii (Figs. 2c, 4c, 5c). The fifth centrum is elongated, 


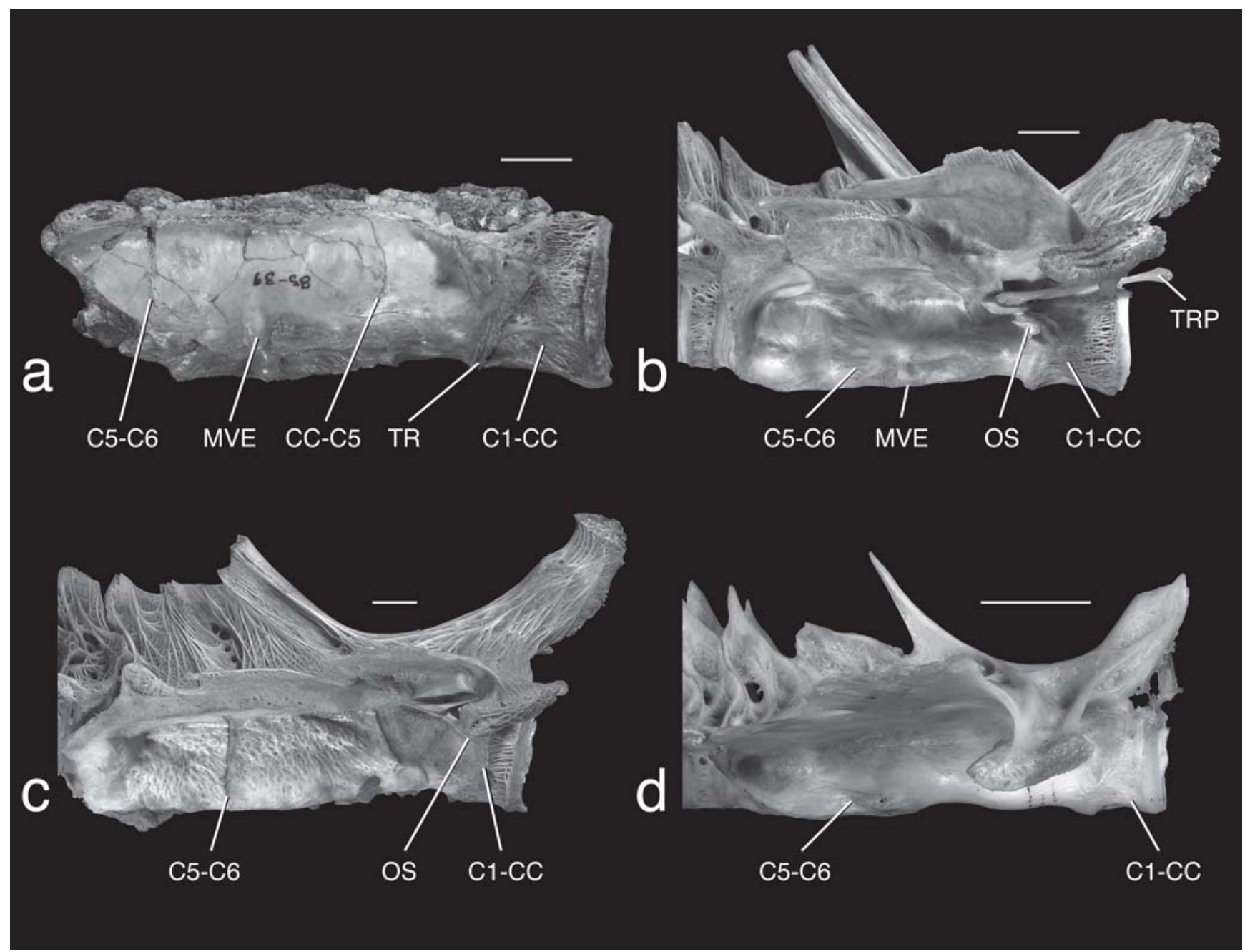

Fig. 5. Weberian complex in right lateral view of the fossil and modern Brachyplatystoma species, a. B. promagdalena, IGM183062, b. B. filamentosum, DU F1052, c. B. rousseauxii, DU F1078, d. B. vaillantii, DU F1034. Scale bars equal to $1 \mathrm{~cm}$. Abbreviations as in Figs. 1, 2 and 4.

its length measured midlaterally on the centra or midventrally from the midpoints of the sutural intervertebral joints, is greater than combined lengths of the first plus compound centra. Laterally the joints bewteen the compound and fifth centra, and fifth and sixth centra are weakly sutural and scarcely interdigitating. The contrasting plesiomorphic states of these characters are found in B. filamentosum (Figs. 2b, 4b, 5b) and B. capapretum as well as other Brachyplatystoma (Figs. 2d, 4d, 5d) and Platynematichthys. In these catfishes the length of the fifth centrum is less than or about equal to the first and compound centra, and the joints between the fifth and its neighboring centra are deeply interdigitating.

Conflicting with its similarities to $B$. rousseauxii, B. promagdalena shares two seemingly derived features with $B$. filamentosum and B. capapretum (Figs. 2a,b, 4 a,b, 5a,b). The first is an irregularly expanded and roughened area midventrally on the fifth centrum. This attachment site of the gas bladder is a distinctive hypertrophied structure in the new species but smaller in the second two species. Second, all three species have a pair of elevated anterolateral pro- cesses between the first and compound centra, although these processes are more prominent in the new species than the other two species. In contrast, in B. rousseauxii (Figs. 2c, 4c, 5c) as well as other Brachyplatystoma (Figs. 2d, 4d, 5d) and Platynematichthys primitively lack enlargement of the fifth centrum and instead its sides are smooth and parallel, and these same species lack the paired anterolateral processes of the first and compound centra.

Lundberg \& Akama (2005, fig. 3, p. 497) presented a phylogenetic analysis of the tribe Brachyplatystomatini comprising the genera Brachyplatystoma and Platynematichthys Adding here $B$. promagdalena to their historical framework yields: (P. notatus ( $B$. vaillantii (B. tigrinum (B. juruense, $B$. platynemum) (B. promagdalena, B. rousseauxii ( $B$. filamentosum, B. capapretum))))). Despite the indecisive resolution of the fossil species within Malacobagrus, B. promagdalena establishes a minimum age of origin of 12.8$13 \mathrm{Ma}$ for the subgenus. Co-occurring with $B$. promagdalena in the La Venta fauna are fragmentary fossils identified as $B$. cf. vaillantii (Lundberg, 1997). Although no more precise iden- 


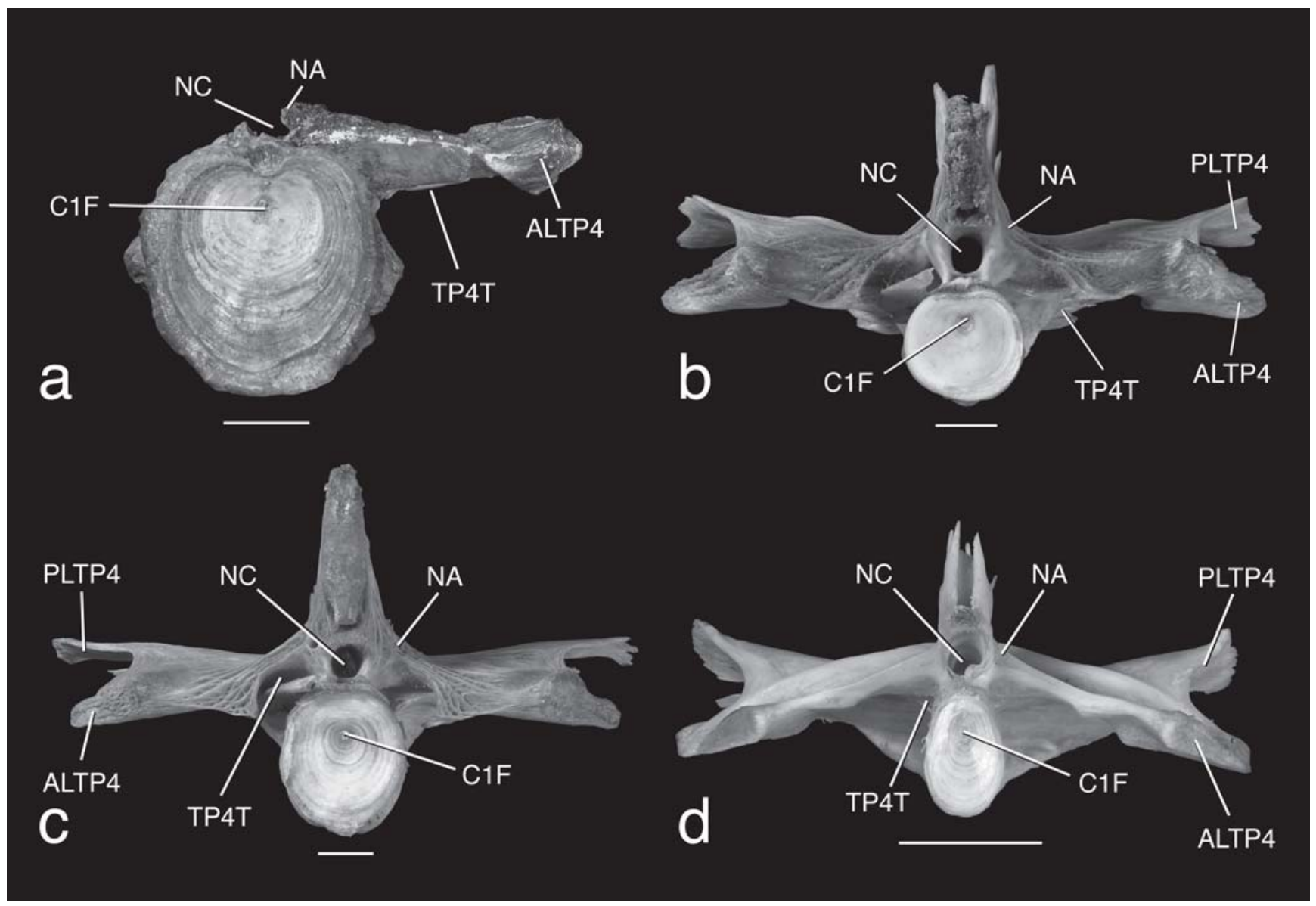

Fig. 6. Weberian complexes in anterior view of the fossil and modern Brachyplatystoma species, a, B. promagdalena, IGM183062, b, B. filamentosum, DU F1052, c, B. rousseauxii, DU F1078, d, B. vaillantii, DU F1034. Scale bars equal to $1 \mathrm{~cm}$. Abbreviations as in Figs. 1 and 2 plus: C1F, central focus of growth rings; TP4T, trough below fourth transverse process.

tification of these fossils can yet be made, the two records of Brachyplatystoma show nested levels of diversification within the genus by middle Miocene. Fossils representing several other modern taxa of Neotropical fishes indicate similar ages of origin and diversification (Arratia \& Cione, 1996; Lundberg, 1998; Gayet \& Meunier, 2003).

The central Colombian fossils of Brachyplatystoma and associated remains of other aquatic animals such as Lepidosiren, Arapaima, Phractocephalus, Colossoma and Chelus, the mata mata turtle, indicate an ancient wider-ranging Amazonian and Orinocoan fauna than today (Lundberg, 1997, 1998). The La Venta fossil localities are in the modern río Magdalena basin from which these genera are now absent. During or after the uplift of the Eastern Andes, as that new drainage divide isolated the trans-Andean Magdalena Valley (Lundberg et al., 1998, fig. 18, p. 38), much of the Amazonian and Orinocoan fauna disappeared from the region. Prior to about $12 \mathrm{Ma}$ before the existence of the Andean Cordillera Oriental, central Colombia was part of the paleo-AmazonasOrinoco system (Hoorn, et al., 1995, Lundberg et al., 1998, fig. 17 , p. 35). The north flowing paleo-Amazonas-Orinoco drained the vast foreland basin area east of the developing
Andean mountain chain from Bolivia and Peru in the south to Colombia and Venezuela in the north. Along the main axis of the foreland basin sedimentary and paleontological evidence records the occasional presence of widespread lacustrine habitats sometimes with marine influence far inland from the Caribbean. Certainly, however, large rivers were always present in this immense system carrying runoff from the Andes, Brazilian and Guiana shields.

An intriguing aspect of the life histories of some Brachyplatystoma is long-distance migration related to reproduction (Barthem \& Goulding, 1997). One of the three living species of Malacobagrus, B. rousseauxii (dourada), as well as B. vaillantii (piramutaba) and B. platynemum (babão) undertake long-distance migrations in the Amazon and probably the Orinoco. Other species of the genus may also migrate or move long distances but data are scant. Adults of the migratory species move upriver to yet undetermined spawning sites. Their larvae, juveniles, and possibly eggs are pelagic developing as they float downstream to nursery areas in the lower basin. Considering the phylogenetic relationship of $B$. promagdalena to the long-distance migrants, it is possible that the extinct species also was migratory in the Mi- 
ocene and perhaps earlier paleo-Amazonas-Orinoco. If so, the principal axis of migratory movement of $B$. promagdalena would have been along the Andean foreland basin, generally south for adults and north for pelagic early stages. It would not stretch the imagination to envision a passive change of goliath catfish migration paths and directions following the shifting courses of South America's largest rivers over spatiotemporal scales encompassing much of the continent and millions of years.

\section{Acknowledgements}

A. Lopez Reina and J. Guerrero Diaz (formerly) at INGEOMINAS, Bogotá, and R Kay (Duke University) made the fossil available for study. R. Madden and L. Benton prepared the epoxy casts. K. Luckenbill executed the digital imaging and illustrations. I am grateful to G. Arratia, W. Dahdul, L. McDade, G. R. Smith and an anonymous reviewer for corrections and helpful suggestions on the manuscript. The U.S. National Science Foundation supported this work through a research grant to J. G. Lundberg (DEB-0089612), and the All Catfish Species Inventory (NSF DEB-0315963) provided support of publication costs.

\section{Literature Cited}

Arratia, G. \& A. Cione. 1996. The record of fossil fishes of southern South America. In: G. Arratia (Ed.), Contributions of southern South America to vertebrate paleontology. Verlag Dr. F. Pfeil, Munich. 340 p.

Barthem, R. \& M. Goulding. 1997. The catfish connection: ecology, migration and conservation of Amazon predators. Columbia University Press, New York. 162 p.

Chardon, M. 1968. Anatomie comparée de l'appareil de Weber et des structures connexes chez les Siluriformes. Annales de Musée Royale de l'Afrique Centrale, Ser. 8, Sciences Zoologiques, 169: 1-227.

Gayet, M. \& F. J. Meunier 2003. Palaeontology and palaeobiogeography of catfishes. Pp. 491-522. In: Arratia, G., B. G. Kapoor, M. Chardon, \& R. Diogo, (Eds.), Catfishes. Science Publishers, Inc., Enfield. 750 p.

Guerrero, J. 1997. Stratigraphy, sedimentary environments and the Miocene uplift of the Colombian Andes. Pp. 15-43 In: R. F. Kay, R. H. Madden, R. L. Cifelli \& J. J. Flynn (Eds.), Vertebrate paleontology in the Neotropics: The Miocene fauna of La Venta, Colombia. Smithsonian Institution Press, Washington. $592 \mathrm{p}$.

Hoorn, C., J. Guerrero, G. A. Sarmiento \& M. A. Lorente. 1995. Andean tectonics as a cause for changing drainage patterns in Miocene northern South America. Geology, 23: 237-240.

Kay, R. F., R. H. Madden, R. L. Cifelli \& J. J. Flynn (Eds.). 1997 Vertebrate Paleontology in the Neotropics: The Miocene fauna of La Venta, Colombia. Smithsonian Institution Press, Washington. 592 p.
Lundberg, J. G. 1997. Fishes of the Miocene La Venta fauna: additional taxa, biotic and paleoenvironmental implications. Pp. 67-91 In: R. F. Kay, R. H. Madden, R. L. Cifelli \& J. J. Flynn (Eds.), Vertebrate paleontology in the Neotropics: The Miocene fauna of La Venta, Colombia. Smithsonian Institution Press, Washington. 592 p.

Lundberg, J. G. 1998. The temporal context for diversification of neotropical fishes. Pp. 49-68 In: L. R. Malabarba, R. E. Reis, R. P. Vari, C. A. S. Lucena \& Z. M. S. Lucena (Eds.), Phylogeny and Classification of Neotropical Fishes. Edipucrs, Porto Alegre. 603p.

Lundberg, J. G., O. Linares, P. Nass \& M. E. Antonio. 1988. Phractocephalus hemioliopterus (Pimelodidae: Siluriformes) from the upper Miocene Urumaco formation, Venezuela: a further case of evolutionary stasis and local extinction among South American fishes. Journal of Vertebrate Paleontology, 8: 131-138.

Lundberg, J. G., F. Mago-Leccia \& P. Nass. 1991. Exallodontus aguanai, a new genus and species of Pimelodidae (Teleostei: Siluriformes) from deep river channels of South America and delimitation of the sub-family Pimelodinae. Proceedings of the Biological Society Washington, 104: 840-869.

Lundberg, J. G., L. G. Marshall, J. Guerrero, B. Horton, M. C. Malabarba \& F. Wesselingh. 1998. The stage for neotropical fish diversification: a history of tropical South American rivers. Pp. 13-48 In: L. R. Malabarba, R. E. Reis, R. P. Vari, C. A. S. Lucena and Z. M. S. Lucena (Eds.), Phylogeny and classification of neotropical fishes. Edipucrs, Porto Alegre. 603p.

Lundberg. J. G. \& B. M. Parisi. 2002. Propimelodus, new genus, and redescription of Pimelodus eigenmanni Van der Stigchel 1946, a long-recognized yet poorly-known South American catfish (Pimelodidae, Siluriformes). Proceedings of the Academy of Natural Sciences, Philadelphia, 152: 75-88.

Lundberg J. G. \& O. Aguilera. 2003. Additional specimens and reinterpretation of the late Miocene Phractocephalus catfish (Pimelodidae, Siluriformes) from Urumaco, Venezuela. Neotropical Ichthyology, 1: 97-109.

Lundberg, J. G. \& M.W. Littmann. 2003. Siluriformes: Family Pimelodidae - Long-whiskered catfishes. Pp. 437-452 In: R. E. Reis, S. O. Kullander \& C. J. Ferraris (Eds.), Check list of freshwater fishes of South and Central Americas. Edipucrs, Porto Alegre. 603 p.

Lundberg, J. G. \& A. Akama. 2005. Brachyplatystoma capapretum: a new species of goliath catfish from the Amazon Basin, with a reclassification of allied catfishes (Siluriformes, Pimelodidae). Copeia, 2005: 492-516.

Received July 2005 Accepted November 2005 